\title{
Bacteria and Fungi as Altematives for Remediation of Water Resources Polluting Heavy Metals
}

\author{
Jin Ho Joo*, Khalid A. Hussein, Sedky H. A. Hassan \\ Department of Biological Environment, Kangwon National University, 192-1 Hyo-Ja Dong, \\ Chuncheon, Kangwon-do 200-701, South Korea
}

\begin{abstract}
Classical methods which used for removal of heavy metals from contaminated water are adsorption, precipitation, coagulation, ion exchange resin, evaporation, and membrane processes. Microbial biosorption can be used for the removal of contaminated waters with pollutants such as heavy metals and dyes which are not easily biodegradable. Microbial biosorbents are inexpensive, eco friendly and more effective for the removal of toxic metals from aqueous solution. In this review, the bacterial and fungal abilities for heavy metals ions removal are emphasized. Environmental factors which affect biosorption process are also discussed. A detailed description for the most common isotherm and kinetic models are presented. This article reviews the achievements and the current status of bacterial and fungal biosorption technology for heavy metals removal and provides insights for further researches.
\end{abstract}

Key words: Biosorption, Microbial biomass, Fungi, Bacteria, Heavy metals

\section{Introduction}

The pollution of heavy metals into aquatic ecosystems has become a complex problem in over the world the last few decades. Presence of heavy metals even in small amounts is toxic to both flora and fauna. Many industries are responsible for this pollution such as mining, surface finishing, energy and fuel producing, fertilizer, pesticide, metallurgy, iron and steel, electroplating, electrolysis, electro-osmosis, leather, photography, electric appliance manufacturing, and metal surface treating. Moreover, the aerospace, atomic energy installations, and wastes containing metals are directly or indirectly being discharged into the environment causing serious environmental pollution (Wang and Chen 2009). Removal and Controlling toxic heavy metal discharges from water bodies has become a challenge for the twenty-first century.

The classical techniques of heavy metals removal such as chemical precipitation, chemical oxidation and reduction, ion-exchange, filtration, electrochemical treatment, and reverse osmosis give rise to several problems such as unpredictable metal ions removal and generation of toxic

\footnotetext{
Received : July 11. 2011 Accepted : August 17. 2011

*Corresponding author : Phone: +82332506448

E-mail: jhjoo@kangwon.ac.kr
}

sludges which are often difficult to dewater and require extreme caution in their disposal (Xia and Liyuan, 2002). Moreover, these classical techniques for heavy-metal removal are extremely expensive cost due to the high reagent or energy requirements (Xia and Liyuan, 2002). The need for economical, effective and safe methods for removing heavy metals from wastewater has resulted in search for unconventional methods that may be useful in reducing the levels of accumulated heavy metals in the environment. Recently, using microbial biomass as biosorbents for heavy metal removal from industrial waste streams has been considered as a potential alternative technology. Most microbial biomasses have a negative charge owing to the presence of negatively charged groups of atoms on the cell membrane and cell wall. The charged groups or ligands are responsible for the adsorption of positively charged metal ions in solution. The adsorption is typically rapid, reversible and independent of temperature and energy metabolism. This phenomenon is known as biosorption. Biosorption, using biomaterials such as bacteria, fungi, yeast and algae, is regarded as a cost-effective biotechnology for the treatment of high volume and low concentration complex wastewaters containing heavy metal(s). Currently, several adsorbents are being used including seaweeds, molds, yeast, bacteria, crabshells, agricultural products which are by-products of agriculture 
and industries. It has been demonstrated that some fungal and bacterial species are typically associated with heavy metal rich substrata and can be even considered as hyper accumulators of heavy metals (Purvis and Halls, 1996, Gadd 1993). Fungi offer a wide range of chemical groups that can attract and sequester heavy metals in their biomass. Potential of filamentous fungi in bioremediation of industrial effluents and waste waters containing heavy metals has been increasingly reported from different parts of the world (Gadd, 1993).

\section{Heavy Metals Removal by Microorganisms}

Metal biosorption by microorganisms is a complex process that depends on the chemistry of the metal ions, cell wall composition of microorganisms, cell physiology, and physicochemical factors such as $\mathrm{pH}$, temperature, time, ionic strength and metal concentration (Hassan et al., 2009; Gabr et al., 2008; Tuzen et al., 2008; GodlewskaZylkiewicz, 2006; Mapoletoet al., 2005; Chaisuksant 2003; Goyalet al., 2003; Volesky 2003; Klimmeket al., 2001; Leung et al., 2001). Removal of toxic heavy metal ions from polluted waste waters by bacterial biomass has been studied extensively in the last few decades (Joo et al., 2010, Hassan et al., 2009; Tuzen et al., 2008; Akhtar et al., 2007; Kadukova and Vircikova 2005; Chaisuksant, 2003; Leung et al., 2001; Veglio et al., 1997; Akthar and Mohan, 1995; Fourest et al., 1994; Volesky, 2003; 1994; 1990). Microbial biomass have the ability to remove heavy metals from contaminated sites by two process; (1) biosorption "an energy-independent binding of metals to cell wall", and (2) bioaccumulation "an energy-dependent process of metal uptake into the cells" (Karna et al., 1999; Gadd, 1992). Both living and non-living microbial biomass of bacteria, fungi and algae have been used in removing toxic metal ions (Kumar et al., 2008; Karna et al., 1999; Kumar et al., 1998; Volesky, 1990; 1994). Metabolismindependent or biosorption essentially involves adsorption process such as ionic and physicochemical adsorption and is considered as the main mechanism present in the case of non-living biomass. A variety of functional groups located on the bacterial cell walls are known to be included in metal biosorption. These involved carboxyl, amine, hydroxyl, phosphate and sulfhydryl groups. The removal of heavy metals by living and non-living biosorbents have been studied (Joo et al., 2010; Kadukova and Vircikova, 2005; Mapoletoet al., 2005; Chaisuksant 2003; Pardo et al., 2003; Goyalet al., 2003; Volesky, 2003; Veglio et al., 1997; Fourest et al., 1994).

Although, metal biosorption by bacterial biomass occurs through complexation, coordination, physical adsorption, chelation, ion exchange, inorganic precipitation and/or a combination of these process (Akhtar et al., 2007; Chen et al., 2005; Tsezos et al., 1995). Such process includes the active participation of several anionic ligands present on the biomass, like phosphoryl, carboxyl, carbonyl, sulfydryl and hydroxyl groups, was used to immobilize metal ions (Volesky, 2003). Also, the ability of any biosorbent depends on biomass characteristics, physicochemical properties of the heavy metals and the environmental conditions i.e., the solution $\mathrm{pH}$, temperature, and interaction with other ions etc (Volesky, 2003).

\section{Bioaccumulation and Biosorption}

It is important to distinguish between active, metabolically mediated metal uptake "an energy-dependent process of metal uptake into the cells" by living cells as opposed to passive metal uptake by non-living biomass "an energyindependent binding of metals to cell wall". The terms bioaccumulation is an intracellular metal accumulation by living cells (Malik, 2004). This process involves metal binding on intracellular compounds, metal binding proteins, intracellular precipitation, methylation and other mechanisms. The uptake process usually involves adsorption of heavy metal ions at the microbial cell wall or cell membrane through interactions with various functional groups and/or transport into the cell with subsequent transformation. It has been proved that, in some cases, growing cells are able to remove metals continuously through internal detoxification mechanisms (Malik, 2004).

While biosorption can be defined as the ability of biological materials to adsorb heavy metals from aqueous solution through physico-chemical pathways of uptake or a property of certain types of inactive, non-living microbial biomass to bind and concentrate heavy metals from even very dilute aqueous solution (Volesky, 2003; Fourest and Roux, 1992). Biological materials (bacteria, fungi, algae and plant biomass) are known for their potential to adsorb heavy metals (Kratochvil and Volesky, 1998; Chang and Hong, 1994). Mechanisms of cell surface sorption are independent of cell metabolism; they are based upon physicochemical interactions between heavy metal ions and functional groups of the cell wall of microorganisms. 
Biosorption is usually a rapid process responsible for metal removal by non-living biomass. It does not depend on temperature, metabolic energy, or the presence of metabolic inhibitors. Biosorbents in the waste materials discarded either from fermentation industries or from rubber plantaions or marine biomass as a source of raw biosorptive materials. Therefore, the biomass can be either living or non-living but non living is preferred as its easy to handle, and the processes is not growth independent as well as it has no physiological constraints. The use of dead microbial biomass for metal removal and sequestration offers some advantages over living cells in that it the dead microbial biomass is less sensitive to toxic heavy metals, and biosorption may not be inhibited by their presence. Because of there is no metabolic activity, it can be easily control the operating conditions such as $\mathrm{pH}$, temperature, time and metal concentration. Moreover, we can improve the efficiency of biosorption by pre treatment of the microbial biomass. Also, metal recovery and regeneration of the biosoorbent is applicable.

\section{Factors Affecting Biosorption}

Biosorption is presented as an alternative to traditional physicochemical means for removing toxic metals from ground-waters and wastewater. The investigation of the efficacy of biosorption "the metal uptake by the microbial biomass" is essential for the industrial application of biosorption, as it gives information about the equilibrium of the process which is necessary for the design of the equipment. The major factors affecting the biosorption process are (1) the contact time (2) initial metal ion concentration, (3) temperature, (4) $\mathrm{pH}$, and (5) biomass concentration in solution (Tomko, 2006).

Contact time effect Contact time is very important parameter for successful biosorption application. The biosorption process of heavy metal by bacterial biomass usually completes rapidly. The biosorption of metals as cadmium, cobalt, copper, zinc, lead, nickel, chromium and uranium by nonliving cells of bacterial biomass, is a rapid process and often reaches equilibrium within several minutes (Özer and Özer, 2003; Kapoor and Viraraghavan, 1997). However, passive uptake of heavy metals by fungi is thought to be physical adsorption or ion exchange at the cell surface, reaching the adsorption equilibrium within 30-40 min (Das et al, 2008). Equilibrium adsorption levels of lead(II) and copper(II) by filamentous fungi present on the corncob surfaces were attained after about 90 minutes of exposure (Jonglertjunya, 2008). Trametes versicolor is a good cadmium biosorbent, as it removes all $\mathrm{Cd}(\mathrm{II})$ ions within 2 hours (Jarosz-Wilkolazka et al., 2002). This appears to be an energy-independent surface binding process that occurs at a rate of about $2 \mathrm{mg} \mathrm{Cd}$ (II) per gram of mycelial dry weight. Rhizopus sp. biosorbed $80 \%$ of $\mathrm{Ni}(\mathrm{II})$ within 2 hours at an initial concentration of $10 \mathrm{ppm}$ (Mogollon et al., 1998). It is necessary to optimize the contact time, considering the efficiency of desorption and regeneration of the biomass. Gabr et al. (2008) optimized the sorption time for $\mathrm{Pb}$ (II) and $\mathrm{Ni}(\mathrm{II})$ by heavy metal resistant strain Pseudomonas aeruginosa ASU 6a. Besides, the results showed that a 30 min sorption period was the best option to ensure the metal removal from solution and good recovery from biosorbent. Similar results were observed by Hassan et al. (2009) who concluded that the optimum time for biosorption of $\mathrm{Cu}$ and $\mathrm{Cd}$ by $P$. stutzeri was $30 \mathrm{~min}$.

pH effect The $\mathrm{pH}$ seems to be the most important parameter in the biosorption process. Solution $\mathrm{pH}$ value strongly influences not only the site dissociation of the biomass surface, but also the solution chemistry of the heavy metals as hydrolysis, complexation by organic and/ or inorganic ligands, redox reactions, precipitation, the speciation and the biosorption availability of the heavy metals (Esposito et al., 2001; Wang et al., 1997). Also, it affects the activity of the functional groups in the biomass and the competition of the metalic ions (Friis and Keith, 1998; Galun et al. 1987). It has been attributed to protonation or poor ionization of acidic functional group of cell wall at low $\mathrm{pH}$, inducing a weak complexation affinity between the cell wall and the metal ions (Chergui et al., 2007). Therefore, at low $\mathrm{pH}$ values the cell surface becomes more positively charged, then reducing the attraction between metal ions and functional groups on the cell wall. In contrast, higher $\mathrm{pH}$ results in facilitation of the metal biosorption, since the cell surface is more negatively charged. The biosorptive capacity of metal cations increases with increasing $\mathrm{pH}$ of the sorption system, but not in a linear relationship. On the other hand, extreme $\mathrm{pH}$ value can cause precipitation of metal complexes, so it should be avoided during experiments. As $\mathrm{pH}$ increases, functional sites on the microbial surface become deprotonated and may bind cationic metals instead. This results in the 
common trend of increasing accumulation with increasing $\mathrm{pH}$. However, in many cases, the accumulation starts to decrease again at higher $\mathrm{pH}$. The metals will transform into hydroxide complexes at high $\mathrm{pH}$ values, however, it could not be considered as a biosorption behavior of the cells. Mapoleto and Torto (2004) proved that the biosorption capacity of $\mathrm{Cd}^{2+}, \mathrm{Cr}^{3+}, \mathrm{Cr}^{6+}, \mathrm{Cu}^{2+}, \mathrm{Pb}^{2+}$ and $\mathrm{Zn}^{2+}$ is dependent on $\mathrm{pH}$. For all studied metal ions, the optimum $\mathrm{pH}$ values in all cases were found to be greater than 5. The optimum $\mathrm{pH}$ for $\mathrm{Cd}^{2+}$ and $\mathrm{Pb}^{2+}$ biosorption is 5.8. Also, Özer and Özer (2003) reported that optimal $\mathrm{pH}$ value for $\mathrm{Pb}$ (II) and $\mathrm{Ni}(\mathrm{II})$ ion uptake is 5.0 by $S$. cerevisiae. $\mathrm{Cr}(\mathrm{VI})$ and some other metals such as arsenic are known to exist as anions meaning that the metal carry negative charge. These anions exhibit different $\mathrm{pH}$ features from metal cations. The biosorption was favourable at low $\mathrm{pH}$ for these anions. In this concern, cell wall ligands of bacterial biomass are protonated at low $\mathrm{pH}$ values, and compete significantly with metal binding. With $\mathrm{pH}$ increase, more ligands such as amino and carboxyl groups, would be exposed leading to attraction between these negative charges and the metals and hence increases in biosorption on to the cell surface. As the $\mathrm{pH}$ increased further, the overall surface charge on cells could become negative and therefore, biosorption of anions decreased again (Khambhaty et al., 2009; Wang and Chen 2006; Park et al., 2005; Tewari et al., 2005).

Metal concentration and Ionic strength There is evidence that at high metal ion concentration, the number of ions sorbed is more than at low metal concentration, where more binding sites were free for interaction (Mukhopadhyay et al., 2007). Most of light metals bind weakly to the negatively charged biomass particles, through electrostatic attraction in which a significant ionic strength effect may be observed in the presence of high concentration of light metals. Kaewsarn (2002) reported that effect of $\mathrm{Na}^{+}$on $\mathrm{Cu}$ (II) uptake was negligible at a concentration of $10 \mathrm{mM}$, and $\mathrm{K}^{+}, \mathrm{Mg}^{2+}$ and $\mathrm{Ca}^{2+}$ reduced the removal efficiency by $4 \%, 11 \%$ and $13 \%$, respectively. Since $\mathrm{Na}, \mathrm{K}, \mathrm{Ca}, \mathrm{Mg}$ are present in many industrial waste waters, it is useful to estimate the extent and interferes of light metals with biosorption of heavy metal by microbial biomass (Goyal et al., 2003; Volesky 2003; Esposito et al., 2001; Pagnanelli et al., 2000). Calcium, which may form specific, coordinate bonds, might be having stronger effect on heavy metal biosorption (Goyal et al., 2003; Volesky, 2003; Esposito et al., 2001; Pagnanelli et al., 2000). However, the effect of ionic strength can be explained via the competition of light metals with the heavy metals for electrostatic binding to the biomass. In addition, Chang and Hong, (1994) noted that the mercury uptake by $P$. aeruginos $a$ decreased with the increment of ionic strength. Also, Cho et al. (1994) showed that no significant decrease in the binding of $\mathrm{Cd}^{2+}$ and $\mathrm{Zn}^{2+}$ occurred up to the ionic strength of $10^{-3} \mathrm{M}$. In contrast, Chaisuksant (2003) illustrated that the presence of light metal ions $\left(\mathrm{Na}^{+}, \mathrm{K}^{+}, \mathrm{Mg}^{2+}\right.$ and $\left.\mathrm{Ca}^{2+}\right)$ in solution had an insignificant effect on cadmium and copper sorption capacity by pretreated biomass of marine alga Gracilaria fisheri. In general, the increase of ionic strength decreased biosorption efficiency because of the increment of electrostatic charge (Volesky, 2003).

Microbial biomass and surface area effect Biosorption generally decreased with increase in biosorbent particle size and its concentration (Zhou, 1999). Fourest and Roux (1992) invalidated this hypothesis attributing the responsibility of the specific uptake decrease due to metal concentration shortage in solution. Biomass concentration in the solution seems to influence the specific uptake; for lower values of biomass concentration lead to interference between the binding sites (Das et al. 2008). Moreover, large quantity of fungal biomass is available from the antibiotic- and food-industries. Ultimately, the biosorption results not only in metal removal but also provides an eco-friendly environment. Hence, this factor needs to be taken into consideration in any application of microbial biomass as biosorbent (Ahalya et al. 2003). The passive part of microbial metal accumulation can be influenced by surface properties such as charge and orientation of the metal binding functional groups on the cell surface. Microorganisms have a high surface area-to-volume ratio as their small size, and therefore this high surface area provide a large contact area that can interact with metals in the surrounding environment. Microbial metal accumulation has received much attention during the last years due to the potential use of microorganisms for cleaning metal-polluted water. However, less attention has been paid to the role of microorganisms for metal mobility in soil even though the same processes might occur there. Metal accumulation by microorganisms is influenced by the surface characteristics of microorganisms, but also themselves can lead to changes in the surface properties such as charge changes (Ivanov et 
al., 1996; Chen and Ting, 1995; Collins and Stotzky 1992).

Temperature effect As the temperature increases, the rate of diffusion of adsorbate molecules across the external boundary layer and interval pores of the adsorbent particle increases (Ho and McKay, 1998). The temperature range of $20-45^{\circ} \mathrm{C}$ apparently exhibited no significant influence on biosorption potential of test fungal species (Javaid et al., 2010). In addition, metal biosorption by non-living biomass is a metabolism independent process and it is not ruled by physiological restriction.

\section{Pretreatment and its effect on the biosortion of heavy} metals Many findings have been reported regarding the use of pre-treated biomass for biosorption of metals. Physical and chemical treatments such as autoclaving, drying, and boiling may affect binding properties, also chemical treatments such as alkali or ethanol treatment can elevate the biosorption capacity, especially evident in some fungal systems because of deacetylation of chitin to form chitosan- glucan complexes with higher metal affinities (Wang and Chen 2006). Pre-treating the fungal biomass can help shed light on the role played by functional groups in biosorption of lead (Parvathi, 2007). The bioadsorption capacity of autoclaved Mucor rouxii decreased as compared to the live fungus, attributed to the loss of intracellular uptake (Yan and Viraraghavan, 2000). On the other hand, Ahuja et al. (1999) found that the use of acid-pretreated Oscillatoria anguistissima resulted in a decline in cobalt adsorption while metal sorption remained unchanged after alkali pretreatment. More detailed studies are required to understand why enhancement or reduction in adsorption capacity occurs under specific pretreatment conditions (Kapoor and Viraraghavan, 1998). Göksungur et al. (2005) suggested that higher metal uptake by ethanol pretreated cells was due to the increase in the availability of binding sites. Arica et al. (2005) added that denaturation of protein molecules and degradation of polysaccharide compounds of the cell wall components also produce additional available binding sites.

\section{Biosrption Isotherms}

Several studies on metal accumulation by microorganisms have been used the adsorption isotherms as a way to describe metal accumulation process. The relationship between the amount of metal ion which adsorbed on the microbial biomass $\left(\mathrm{q}_{\mathrm{eq}}\right)$ and the metal ion concentration remaining in solution $\left(\mathrm{C}_{\mathrm{eq}}\right)$, is described by an isotherm equation. Also, the isotherm represents the equilibrium distribution of metal ions between the aqueous and solid phase. Thereby, the equilibrium distribution is an important in determination the maximum biosorption capacity. Several isotherm models are available to describe this equilibrium distribution such as Freundlich, Langmuir, Redlich-Paterson, BET, and the Sips equation. The two most commonly used models for describing this type of system are those given by Langmuir and Freundlich.

Langmuir isotherm The most widely applied isotherm for equilibrium data modeling. Langmuir adsorption isotherm is based on some assumptions, mainly, the adsorption is limited to monolayer coverage, all surface sites are energetically equivalent, each site can hold one ion, and the adsorption is localized. The Langmuir equation can be written in the following form:

$$
q_{e q}=\frac{q_{\max } b C_{e}}{1+b C_{e}}
$$

While, the linear form of Langmuir equation is

$$
C_{e q} / q=1 / q_{\max } b+C_{e q} / q_{\max }
$$

Where $q_{\max }$ is the Langmuir constant $(\mathrm{mg} / \mathrm{g})$ reflect the maximum adsorption capacity of the metal ion per unit weight of microbial biomass to form a complete monolayer on the surface bound at high $C_{e q}$. The value of Langmuir constant $b(\mathrm{~L} / \mathrm{mg})$, represents a ratio of adsorption rate constant to desorption rate constant, which also gives an indication of the affinity of the metal for binding sites on the biosorbent, $q_{\max }$ and $\mathrm{b}$ can be determined from the linear form of Langmuir equation (2) by plotting $C_{e q} / q_{e q}$ vs $C_{e q}$ (Hassan et al., 2009; Norton et al., 2004; Volesky, 2003; Aksu and Dönmez 2001; Puranik and Paknikar 1999; Veglio et al., 1997; Chong and Volesky, 1995; Volesky and Holan, 1995). Langmuir model was chosen to estimate the maximum adsorption capacity corresponding to complete monolayer coverage on the biomass surface. On the other hand, Freundlich model was chosen to estimate the adsorption intensity of the biosorbent towards the biomass.

Freundlich adsorption isothem Freundlich expression is an empirical equation based on the sorption on a heterogeneous surface. It models monolayer adsorption 
on a heterogeneous surface and the equation is written as:

$$
q_{e q}=K C_{e q}^{1 / n}
$$

The linearized form of this model is;

$$
\ln q_{e q}=\ln K_{f}+1 / n \ln C_{e q}
$$

where $K_{f}$ and $\mathrm{n}$ are the Freundlich constants characterizing of the system. Equation 3 can be linearized in logarithmic form (eq. 4) and Freundlich constants can be determined.

Freundlich isotherm is also more widely used but provide no information on the monolayer adsorption capacity. In contrast to Langmuir model, Freundlich equation measures the adsorption capacity $K_{f}$, and the intensity of adsorption (n). (Hassan et al., 2009; Goyal et al., 2003; Volesky, 2003; Chong and Volesky, 1995; Mattuschka and Strauble, 1993; Aksu and Dönmez 2001; Puranik and Paknikar, 1999).

\section{Biosorption Kinetics}

Kinetic studies of heavy metal biosorption is probably one of the most important factorin biosorption system design being the residence time and the reactor dimensionscontrolled by the system kinetics. For batch kinetics of heavy metal biosorption are generallycharacterized by an initial rapid diminution of heavy metal concentration in the liquid phase followed by a second slower and insignificant decrease. The study of biosorption kinetics for heavy metals removal from water ecosysten is significant as it provides valuable insights for the reaction directions and into the reaction mechanisms. Monitoring a kinetic experiment enables us to see how the sorption system is affected by process variables and to understand the steps which limit sorption. Also, the kinetics describes the solute uptake rate which in turn controls the residence time of sorbate accumulated at the solid-solution interface, determination the sorption processes. So, it is necessary to be able to expect the reaction rate at which heavy metals is removed from aqueous solutions in order to design appropriate sorption treatment plant. There are numerous biosorption kinetics models have been studied in order to investigate the biosorption processes. Some of these kinetic models included the pseudo-first-order kinetic model, and the pseudo-secondorder kinetic model. Other models also used for description of kinetic studies such as
Elvoich kinetic model, and the Weber and Morris (WM) sorption kinetic model. In the review we will focus for the first two models.

The pseudo-first-order kinetic model The Lagergren rate equation is one of the most widely used sorption rate equations for the sorption of a solute from a liquid solution. Lagergren's first-order rate equation described the adsorption rate on the base of the biosorption capacity $t$ may be represented as

$$
\mathrm{d} q_{\mathrm{t}} / \mathrm{d} t=k_{1}\left(q_{e q}-q_{\mathrm{t}}\right)
$$

where $q_{t}$ is the amount of metal ions adsorbed $(\mathrm{mg} / \mathrm{g})$ at any given time $t(\mathrm{~min}), q_{e}$ is the amount of metal ions adsorbed $\left(\mathrm{mg} / \mathrm{g}\right.$ ) at equilibrium and $K_{1}$ is the rate constant of pseudo-first-order reaction rate constant for biosorption $\left(\min ^{-1}\right)$.

Integration by applying the boundary conditions $q_{t}=0$ at $t=0$ and $q_{t}=q_{t}$ at $t=t$, gives:

$$
\log \left(q_{e q} / q_{e q}-q_{t}\right)=\left(k_{1} t\right) / 2.303
$$

A plot of $\log \left(q_{e q}-q_{t}\right)$ against $\mathrm{t}$ should give a straight line to confirm the applicability of the first-order kinetic model. In a true first order process $\log q_{e q}$ should be equal to the intercept of a plot of $\log \left(q_{e q}-q_{t}\right)$ against $t$. In most cases in the literature, the pseudo-first-order equation of Lagergren does not fit well for the whole range of contact time of heavy metals biosorption. Pseudo-first order model have been applied to many biosorption kinetic studies (Febrianto et al., 2009).

The pseudo-secondorder kinetic model A pseudosecond-order model proposed by Ho and McKay (1999) was then used to explain the biosorption kinetics. This model is based on the assumption that the adsorption follows second order chemisorptions and predicts the behavior over the whole range of concentration and is in agreement with an adsorption mechanism being the rate controlling step. Other assumptions for description of the type of kinetic model are almost similar to Langmuir adsorption isotherm model, such as;

(1) A monolayer of heavy metal ions on the surface of sorbent will be formed.

(2) The energy of biosorption for each metal ion is equivalent and independent of surface coverage. 
Table 1. Important results from the literature for metal biosorption by various bacterial biomass.

\begin{tabular}{|c|c|c|c|c|}
\hline Metal & Biosorbent & $\mathrm{pH}$ & $\mathrm{q}_{\max }(\mathrm{mg} / \mathrm{g})$ & References \\
\hline \multirow[t]{17}{*}{ Copper } & Bacillus sp. (ATS-1) & 5 & 16.3 & Tunali et al., 2006 \\
\hline & Bacillus subtilis IAM 1026 & 5 & 20.8 & Nakajima et al., 2001 \\
\hline & Enterobacter $s p . J 1$ & 5 & 32.5 & Lu et al., 2006 \\
\hline & Micrococcus luteus IAM 1056 & 5 & 33.5 & Nakajima et al., 2001 \\
\hline & Pseudomonas aeruginosa PU21 & 5 & 23.1 & Chang et al., 1997 \\
\hline & Pseudomonas cepacia & 7 & 65.3 & Savvaidis et al., 2003 \\
\hline & Pseudomonas putida & 6 & 6.6 & Pardo et al., 2003 \\
\hline & Pseudomonas putida & 5.5 & 96.9 & Uslu and Tanyol, 2006 \\
\hline & Pseudomonas putida $C Z$ & 4.5 & 15.8 & Chen et al., 2005 \\
\hline & Pseudomonas stutzeri IAM 12097 & 5 & 22.9 & Nakajima et al., 2001 \\
\hline & Sphaerotilus natans & 6 & 60 & Beolchini et al., 2006 \\
\hline & Streptomyces coelicolor & 5 & 66.7 & Öztürk et al., 2004 \\
\hline & Thiobacillus ferrooxidans & 6 & 198.5 & Ruiz-Manriquez et al., 1997 \\
\hline & Paenibacillus jamilae & 6 & 7.8 & Morillo et al., 2008 \\
\hline & Pseudomonas pseudoalcaligenes & 5 & 48.4 & Leung et al., 2001 \\
\hline & Pseudomonas aeruginosa AT18 & 5 & 113.64 & Pérez Silva et al., 2009 \\
\hline & Pseudomonas stutzeri & 5 & 33.16 & Hassan et al., 2009 \\
\hline \multirow[t]{11}{*}{ Cadmium } & Aeromonas caviae & 7 & 155.3 & Loukidou et al., 2004 \\
\hline & Bacillus circulans & 7 & 26.5 & Yilmaz and Ensari, 2005 \\
\hline & Enterobacter sp. J1 & 6 & 46.5 & Lu et al., 2006 \\
\hline & Pseudomonas aeruginosa PU21 & 6 & 42.4 & Chang et al., 1997 \\
\hline & Pseudomonas putida & 6 & 8 & Pardo et al., 2003 \\
\hline & Pseudomonas sp. & 7 & 278 & Ziagova et al., 2007 \\
\hline & Staphylococcus xylosus & 6 & 250 & Ziagova et al., 2007 \\
\hline & Streptomyces pimprina & 5 & 30.4 & Puranik et al., 1995 \\
\hline & Paenibacillus jamilae & 6 & 20.4 & Morillo et al., 2008 \\
\hline & Pseudomonas aeruginosa & 8.5 & 6.18 & Tuzen et al., 2008 \\
\hline & Streptomyces rimosus & 8 & 64.9 & Selatnia et al., 2004 \\
\hline \multirow[t]{13}{*}{ Lead } & Bacillus sp. (ATS-1) & 3 & 92.3 & Tunali et al., 2006 \\
\hline & Corynebacterium glutamicum & 5 & 567.7 & Choi and Yun, 2004 \\
\hline & Enterobacter sp. $J 1$ & 5 & 50.9 & Lu et al., 2006 \\
\hline & Pseudomonas aeruginosa & 5 & 79.5 & Chang et al., 1997 \\
\hline & Pseudomonas aeruginosa & 5 & 0.7 & Lin and Lai, 2006 \\
\hline & Pseudomonas putida & 5.5 & 270.4 & Uslu and Tanyol, 2006 \\
\hline & Pseudomonas putida & 6.5 & 56.5 & Pardo et al., 2003 \\
\hline & Streptomyces rimosus & 6.5 & 135 & Selatnia et al., 2004 \\
\hline & Streptoverticillium cinnamoneum & 4 & 57.7 & Puranik and Paknikar, 1997 \\
\hline & Paenibacillus jamilae & Not available & 303.03 & Morillo et al., 2008 \\
\hline & Pseudomonas aeruginosa & 8.5 & 6.07 & Tuzen et al., 2008 \\
\hline & Pseudomonas pseudoalcaligenes & 5 & 271.7 & Leung et al., 2001 \\
\hline & Pseudomonas aeruginosa $A S U 6 a$ & 6 & 123 & Gabr et al., 2008 \\
\hline \multirow[t]{6}{*}{ Nickel } & Streptomyces coelicolor & 8 & 11.1 & Öztürk et al., 2004 \\
\hline & Streptomyces rimosus & 6.5 & 36 & Selatnia et al., 2004 \\
\hline & P. aeruginosa $A S U 6 a$ & 7 & 113.6 & Gabr et al., 2008 \\
\hline & Pseudomonas aeruginosa & 8.5 & 5.25 & Tuzen et al. 2008 \\
\hline & Escherichia coli & 7 & 34.3 & Kao et al., 2008 \\
\hline & Paenibacillus jamilae & 6 & 17.6 & Morillo et al., 2008 \\
\hline \multirow[t]{8}{*}{ Zinc } & Paenibacillus jamilae & 6 & 12.31 & Morillo et al., 2008 \\
\hline & Escherichia coli & 7 & 659 & Kao et al., 2008 \\
\hline & Pseudomonas aeruginosa AT18 & 7.-7.2 & 87.72 & Pérez Silva et al., 2009 \\
\hline & Pseudomonas putida & 7 & 6.9 & Pardo et al., 2003 \\
\hline & Pseudomonas putida & 5 & 17.7 & Chen et al., 2005 \\
\hline & Streptomyces rimosus & 3 & 30 & Mameri et al., 1999 \\
\hline & Streptomyces rimosus & 3 & 80 & Mameri et al., 1999 \\
\hline & Streptoverticillium cinnamoneum & $5.0-6.0$ & 21.3 & Puranik and Paknikar, 1997 \\
\hline
\end{tabular}


(3) The bisorption occurs only on localized sites.

(4) No interactions between sorbed ions.

(5) The rate of reactions is almost negligible for the initial rate of biosorption processes.

The pseudo-second-order model can be expressed as:

$$
\frac{d q}{d t}=k_{2}\left(q_{e}-q\right)^{2}
$$

Which have the linear form

$$
\left(1 / q_{t}\right)=\left(1 / k_{2} q_{\mathrm{eq}} t\right)+\left(1 / q_{\mathrm{eq}}\right)
$$

where $q_{t}$ is the amount of metal ions adsorbed to dry biomass of $N$. commune $(\mathrm{mg} / \mathrm{g})$ at any given time $t(\mathrm{~min})$, $q_{e}$ is the amount of metal ions adsorbed $(\mathrm{mg} / \mathrm{g})$ at equilibrium and $K_{2}$ is the second-order reaction rate constant for adsorption ( $\mathrm{g} /(\mathrm{mg} \mathrm{min})$. The rate constant $\left(k_{2}\right)$ and adsorption at equilibrium $\left(q_{\mathrm{eq}}\right)$ can be obtained from the intercept and slope, respectively. Pseudo-second order kinetic model is generally more suitable than pseudo-first order model to represent kinetic data of heavy metal biosorption in batch models. In many biosorption studies the regression coefficients higher than 0.98 were obtained and the calculated amount the amount of metal ions adsorbed $(\mathrm{mg} / \mathrm{g})$ at equilibrium time $\left(\mathrm{q}_{\mathrm{e}}\right)$ values agreed well with experimental ones (Febrianto et al. 2009). In recent study by Joo et al. (2010), for biosorption of $\mathrm{Zn}$ (II) by gram negative and gram positive bacteria, the biosorption processes fit well with pseudo-second order kinetic model than pseudo-first order model.

\section{Bacterial Biosorption of Heavy Metals}

Removal of toxic heavy metal ions may contribute to the detoxification of polluted environments. Therefore, the investigation of metal uptake by bacteria is fundamental for the application of biosorption, since it gives information about metal ions removal efficiency in the process (Veglió, and Beolchini, 1997). Different kinds of bacterial species were used for the biosorption and removal of heavy metal ions. Table 1 summarizes some of the important results of heavy metal biosorption using bacterial biomass.

Table 1 shows the maximum biosorption capacity of heavy metals by bacteria reported in literature. However, the direct comparison of experimental data is not possible, due to different in experimental conditions employed (such as; $\mathrm{pH}$, equilibrium time, temperature, biomass concentration, heavy metal concentrations and the bacterial biomass). Even so, Table 1 provides some information to evaluate the possibile usage of bacterial biomass for the removal of heavy metal ions. Also, the biosorption capacity is not only depends on the type of heavy metal ions, but also on the type of bacteria, due to the variations in cellular constituents.

\section{Fungal Biosorption of Heavy Metals}

Fungi and yeasts have been shown to biosorb heavy metals metal ions from aqueous solutions (Singh 2006; Kapoor and Viraraghavan 1995). The most common species that used for heavy metals removal are, Saccharomyces cerevisiae, Penicillium sp., Phanerochaete chrysogenum was studied most. The species of Penicillium was observed to sorb uranium and lead well (Wang and Chen 2009). The living fungal cells of $A$. niger, $M$. rouxii and $R$. arrhizus have been shown to take up precious metals such as gold and silver (Mullen et al. 1992). The biosorption kinetics of heavy metals is depend on contact time. Also, the fungal biosorption of heavy metal ions is strongly depends on $\mathrm{pH}$ (Table 2). Biosorption of $\mathrm{Ni}, \mathrm{Cd}$, and $\mathrm{Pb}$ by $P$. digitatum was observed to be inhibited below $\mathrm{pH} 3.0$ (Kapoor and Viraraghavan 1995). Heavy metals biosorption can take place by living cell or dead cell of fungal biomass. Table 2 shows the maximum biosorption capacity of heavy metals by fungi reported in literature. Fungi, such as Aspergillus niger and Mucor rouxii are capable of removing heavy metals from aqueous solutions (Yan and Viraraghavan, 2008). Basidiomycetes (wood rotting fungi) are useful source of mycelial biomass for biosorption of metal ions, being easy to cultivate, acquire high yield and generally regarded as safe. Therefore, biosorbents made from these fungi can be easily accepted by public when applied practically. The potential of wood rotting fungi to remove metal ions is limited to a few examples in comparison with micromycetes and the role of macromycetes in this field has been known only for few decades (Veit et al., 2005; Jarosz-Wilkolazka et al., 2006; Gonen et al., 2008; Vimala and Das, 2009). White-rot fungi are capable of accumulating high levels of heavy metals from the environment (Baldrian, 2003). In some cases, their ability to bind metals is same or even better, than that of lower fungi and yeast (Javaid and Bajwa, 2008). The ability of the basidiomycetes to adsorb and accumulate 
Table 2. Important results from the literature for metal biosorption by various fungal biomass.

\begin{tabular}{|c|c|c|c|c|}
\hline Metal & Biosorbent & $\mathrm{pH}$ & $\mathrm{q}_{\max }(\mathrm{mg} / \mathrm{g})$ & References \\
\hline \multirow[t]{2}{*}{$\mathrm{Au}$} & Aspergillus niger & 2.5 & 199 & Kuyucak et al., 1988 \\
\hline & Rhizopus arrizus & 2.5 & 160 & Kuyucak et al., 1988 \\
\hline \multirow[t]{2}{*}{$\mathrm{Ag}$} & Rhizopus arrhizus & 4.2 & 54 & Tobin et al., 1984 \\
\hline & Sacchromyces cerevisiae & 5.0 & 4.7 & Brady and Duncan, 1993 \\
\hline \multirow[t]{16}{*}{$\mathrm{Cd}$} & Candida tropicalis & 6.0 & 60 & Mattuschka et al., 1993 \\
\hline & Aspergillus terreus & 6.0 & 6.0 & Massaccesi et al., 2002 \\
\hline & Pencillium chrysogenum & 3.5 & 56 & Holan and Volesky, 1995 \\
\hline & Penicillium chrysogenum & $4.0-5.0$ & 11 & Niu et al., 1993 \\
\hline & Mucor rouxii & 5.0 & 8.46 & Yan and Viraraghavan, 2003 \\
\hline & Rhizopus arrhizus & 4.2 & 30 & Tobin et al., 1984 \\
\hline & Fusarium flocciferum & $7.5-8.0$ & 192 & Delgado et al., 1998 \\
\hline & Aspergillus oryzae & 8.0 & 10 & Kiff and Little 1986 \\
\hline & Sacchromyces cervisiae & 4.5 & $2-40$ & Volesky et al., 1993 \\
\hline & Rhizopus arrhizus & 6.0 & 27 & Fourest and Roux, 1992 \\
\hline & Rhizopus nigricans & 3.5 & 19 & Holan and Volesky, 1995 \\
\hline & Polyporus versicolor & 6.0 & 12 & Yetis et al., 1998 \\
\hline & Phanerochaeta chrysosporium & 6.0 & 15 & Yetis et al., 1998 \\
\hline & Penicillium chrysogenum & 6.0 & 23 & Say et al., 2001 \\
\hline & Penicillium chrysogenum & 4.5 & 15.2 & Li et al., 2004 \\
\hline & Fomitopsis pinicola & 6.2 & 51 & Gabriel et al., 1996 \\
\hline \multirow[t]{4}{*}{$\mathrm{Cr}(\mathrm{VI})$} & Rhizopus arrhizus & 4.2 & 31 & Tobin et al., 1984 \\
\hline & Rhizopus arrhizus & 2.0 & 8.4 & Sag and Kutsal, 2000 \\
\hline & Rhizopus nigricans & 2.0 & 212 & Bai and Abraham, 2002 \\
\hline & Candida tropicalis & 6.0 & 4.6 & Mattuschka et al., 1993 \\
\hline \multirow[t]{2}{*}{$\mathrm{Cr}(\mathrm{III})$} & Mucor meihi & 4.0 & 45 & Tobin and Roux, 1998 \\
\hline & Polyporus versicolor & 6.0 & 18 & Yetis et al., 1998 \\
\hline \multirow[t]{16}{*}{$\mathrm{Cu}$} & Candida tropicalis & 6.0 & 80 & Mattuschka et al., 1993 \\
\hline & Cladosporium resinae & 6.0 & 18 & Gadd et al., 1988 \\
\hline & Rhizopus arrhizus & 6.0 & 16 & Yin et al., 1999 \\
\hline & Saccharomyces crevisae & 5.0 & $17-40$ & Mattuschka et al., 1993 \\
\hline & Penicillium chrysogenum & $4.0-5.0$ & 9 & Niu et al., 1993 \\
\hline & Aspergillus oryzae & 5.0 & 55 & Huang, 1996 \\
\hline & Polyporus versicolor & 6.0 & 7.5 & Yetis et al., 1998 \\
\hline & Phanerochaete chrysosporium & 6.0 & 15 & Yetis et al., 1998 \\
\hline & Penicillium chrysogenum & 6.0 & 20.2 & Say et al., 2001 \\
\hline & Penicillium chrysogenum & 6.0 & 100 & Sing and $\mathrm{Yu}, 1998$ \\
\hline & Ganoderma lucidum & 5.0 & 64.4 & Rao, et al., 1993 \\
\hline & Fusarium flocciferum & 4.5 & 40 & Delgado, 1998 \\
\hline & Mucor miehi & 4.0 & 19 & Brady, et al., 1999 \\
\hline & Penicillium digitatum & 5.5 & 14.6 & Galun, et al., 1987 \\
\hline & Aspergillus niger & 5.0 & 10 & Rao, et al., 1993 \\
\hline & Aureobasidium pullulans & 5.5 & 6 & Gadd et al., 1988 \\
\hline \multirow[t]{8}{*}{$\mathrm{Pb}$} & Mucor miehi & 6.0 & 53.75 & Tobin and Roux, 1998 \\
\hline & Rhizopus arrizus & 6.0 & 126 & Yin et al., 1999 \\
\hline & Penicillium chrysogenum & $4.0-5.0$ & 116 & Niu et al., 1993 \\
\hline & Mucor rouxii & 5.0 & 35.69 & Yan and Viraraghavan, 2003 \\
\hline & Phomopsis sp. & 6.0 & 180 & Saiano et al., 2005 \\
\hline & Penicillium chrysogenum (Resting cells) & 5.0 & 80 & Yetis et al., 2000 \\
\hline & Penicillium chrysogenum & 6.0 & 69.8 & Say et al., 2001 \\
\hline & Penicillium chrysogenum & 4.5 & 12.34 & Li et al., 2004 \\
\hline
\end{tabular}


Continued

\begin{tabular}{|c|c|c|c|c|}
\hline Metal & Biosorbent & $\mathrm{pH}$ & $\mathrm{q}_{\max }(\mathrm{mg} / \mathrm{g})$ & References \\
\hline \multirow[t]{8}{*}{$\mathrm{Ni}$} & Mucor miehi & 6.0 & 20.49 & Tobin and Roux, 1998 \\
\hline & Fusarium flocciferum & 7.5 & 52 & Delgado et al., 1998 \\
\hline & Rhizopus arrizus & 2.0 & 10.3 & Sag and Kutsal, 2000 \\
\hline & Mucor rouxii & 5.0 & 11.09 & Yan and Viraraghavan, 2003 \\
\hline & Phomopsis sp. & 6.0 & 6.4 & Saiano et al., 2005 \\
\hline & Polyporus versicolor & 6.0 & 27 & Yetis et al., 1998 \\
\hline & Phanerochaete chrysosporium & 6.0 & 13.5 & Yetis et al., 1998 \\
\hline & Polyporus versicolor & 5.0 & 57 & Dilek et al., 2002 \\
\hline \multirow[t]{12}{*}{$\mathrm{Zn}$} & Mucor miehi & 6.0 & 53.85 & Tobin and Roux, 1998 \\
\hline & Rhizopus arrizus & 6.0 & 34.66 & Yin et al., 1999 \\
\hline & Mucor rouxii & 5.0 & 7.75 & Yan and Viraraghavan, 2003 \\
\hline & Aspergillus oryzae & $2.0-5.0$ & 17.6 & Volesky, 1994 \\
\hline & Penicillium digitatum & 5.5 & 17 & Galun et al., 1987 \\
\hline & Trichoderma reesii & 5.5 & 15.7 & Volesky, 1994 \\
\hline & Rhizopus nigricans & 5.5 & 14.4 & Volesky, 1994 \\
\hline & Aspergillus niger & 5.5 & 13.7 & Volesky, 1994 \\
\hline & Endothia parasitica & $4.0-5.0$ & 9.8 & Volesky, 1994 \\
\hline & Penicillium chrysogenum & 4.5 & 6.2 & Niu, et al., 1993 \\
\hline & Rhizopus arrizus & 5.5 & 13.93 & Zhou, 1999 \\
\hline & Phomopsis sp. & 6.0 & 8.5 & Saiano et al., 2005 \\
\hline \multirow[t]{2}{*}{$\mathrm{Fe}(\mathrm{III})$} & Rhizopus arrizus & 2.0 & 3.9 & Sag and Kustal, 2000 \\
\hline & Penicillium digitatum & 5.5 & 15 & Galun et al., 1987 \\
\hline \multirow[t]{2}{*}{$\mathrm{Fe}(\mathrm{II})$} & Neurospora crassa & 5.1 & 295.3 & Rashmi et al., 2004 \\
\hline & Penicillum citrinum & 5.1 & 126.4 & Rashmi et al., 2004 \\
\hline \multirow[t]{3}{*}{ Co } & Aspergillus niger & $4.0-5.0$ & 95 & Kuyucak and Volesky, 1988 \\
\hline & Rhizopus arrizus & 6.5 & 2.9 & Sakaguchi and Nakajima, 1991 \\
\hline & Aspergillus niger & 6.5 & 2.4 & Sakaguchi and Nakajima, 1991 \\
\hline \multirow[t]{9}{*}{ U } & Aspergillus niger & 5.8 & 220 & Yakubu and Dudeney, 1986 \\
\hline & Rhizopus arrizus & $4.0-5.0$ & 180 & Tsezos and Volesky, 1981 \\
\hline & Penicillium chrysogenum & $2.0-5.0$ & 165 & Tsezos and Volesky, 1981 \\
\hline & Rhizopus nigricans & $4.0-5.0$ & 114 & Kuyucak and Volesky, 1988 \\
\hline & Aspergillus niger & $4.0-5.0$ & 31 & Tsezos and Volesky, 1981 \\
\hline & Trichoderma reesii & $4.0-5.0$ & 28.6 & Kuyucak and Volesky, 1988 \\
\hline & Endothia parasitica & $4.0-5.0$ & 23.85 & Kuyucak and Volesky, 1988 \\
\hline & Penicillium digitatum & 5.5 & 10 & Galun et al., 1987 \\
\hline & Aspergillus terreus & $2.0-5.0$ & 0.95 & Tsezos and Volesky, 1981 \\
\hline
\end{tabular}

metals together with excellent mechanical properties of fungal mycelia provides an opportunity to utilize such candidates in selective sorption of industrial heavy metal ions from polluted waters (Bayramoglu et al., 2007; Razmovski and Šćiban, 2008). Table 2 gives the biosorptive capacities of various fungal biomass to different heavy metals.

\section{Conclusions and Future Perspectives}

Bacterial and fungal biomass represents an efficient and an economically feasible technology for the removal of heavy metal ions from solutions. In this concern, bacterial and fungal biomass (living/non-living cells) can be applied to the mixed contaminated water for the removal of several heavy metals within short time. Several researchers identified superior biosorption performance of bacterial and fungal biomass compared to other adsorbents. Consequently, the application of biosorption using living cells has obtained attention compared to dead cells in addition to growing microbes as a useful alternative for heavy metal contaminants from industrial waste were recommended (Malik, 2004). The optimization of biosorption characteristics and physical conditions is required as additional trend for developing biomaterial immobilization as reuse, recycling and metalmicrobes interactions (Wang and Chen, 2006).It is cleared 
that biosorption of heavy metals is self-driven and don't disturb the sites in cleaning process. Also, biosorption could contribute to conventional methods as a second or pretreatments that enhanced the efficiency of heavy metal removal from industrial wastes and wastewater. Further researches are required to focus on low cost biosorbents as it is difficult to create a definite protocol that could be applied to any contaminated water and wastewater. So, each biosorbents must be customized and adapted to sitespecific conditions. Modeling, regeneration and immobilization of biosorbents are required impressive investigations. The physico-chemical properties of the bacterial or fungal biosorbents need to be studied and how to improve the nature of bacterial and fungal cells for increasing the biosorption capacity of toxic metals ions needs to be developed. Techniques for biosorbent regeneration and their effects on the biosorbent quality should also be evaluated. The biosorption rate for heavy metals, and multi-ions biosorption, should be studied to serve as a basis for the design of biosorption treatment systems. Further studies in real stream water contaminated sites with pollutants should be conducted and finally preliminary design and economic studies should follow.

\section{Acknowledgement}

This study was supported by a National Research Foundation of Korea Grant Funded by the Korean Government (Project Number: 2010-0011988).

\section{References}

Ahalya, N., T.V. Ramachandra, and R.D. Kanamadi. 2003. Biosorption of heavy metals. Res. J. Chem. Environ. 7:71-78.

Ahuja, P., R. Gupta, and R.K. Saxena. 1999. Sorption and Desorption of Cobalt by Oscillatoria anguistissima. Curr Microbiol. 39:49-52.

Akhtar, K., M.W. Akhtar, and A.M. Khalid. 2007. Removal and recovery of uranium from aqueous solutions by Trichoderma harzianum. Wat. Res. 41:1366-1378.

Aksu, Z. and G. Dönmez 2001. Comparison of copper(II) biosorptive properties of live and treated Candida sp. J. Environ. Sci. Health. 36:367-381.

Akthar, M.N. and P.M. Mohan. 1995. Bioremediation of toxic metal ions from polluted lake waters and industrial effluents by fungal biosorbent. Curr. Sci. 69:1028-1030.

Arica, M.Y., I. Tüzün, E. Yalcin, Ö. Ince, and G. Bayramolu. 2005. Utilisation of Native, Heat and Acid-Treated Microalgae Chlamydomonas reinhardtii Preparations for Biosorption of $\mathrm{Cr}$ (VI) ions. Process Biochem. 40:2351-2358.

Bai, R.S. and T.E. Abraham 2002. Studies on enhancement of
$\mathrm{Cr}(\mathrm{VI})$ biosorption by chemically modified biomass of Rhizopus nigricans. Water Res. 36:1224-1236.

Baldrian, P. 2003. Interactions of heavy metals with white-rot fungi. Enz. Microb. Techol. 32:78-91.

Bayramoglu, G., G. Celik, E. Yalcin, M. Yilmaz, and Arica. M.Y. 2007. Modification of surface properties of Lentinus sajor-caju mycelia by physical and chemical methods: evaluation of their $\mathrm{Cr}^{6+}$ removal efficiencies from aqueous medium. J. Hazard. Mat. 119:219-229.

Beolchini, F., F. Pagnanelli, L. Toro, F. Vegliò. 2006. Ionic strength effect on copper biosorption by Sphaerotilus natans: equilibrium study and dynamic modeling in membrane reactor. Wat. Res. 40:144-152.

Brady, J.M. and J.R. Duncan. 1993. Bioaccumulation of cations by Sacchromyces cerevisae in Biohydrometallurgical Technologies. Proceedings of the international biohydrometallurgical symposium, Torma, A.E., Apel, M.L. and Brierley, C.L., (eds), The Minerals, Metals and Materials Society, warrendale, PA. 35-44.

Brady, J.M., J.M. Tobin, and J.C. Roux. 1999. Continuous fixed bed biosorption of $\mathrm{Cu}^{2+}$ ions: application of a simple two parameter mathematical model, J. Chem. Tech. Biotechnol. 74:71-77.

Chaisuksant, Y. 2003. Biosorption of cadmium(II) and copper(II) by pretreated biomass of marine alga Gracilaria fisheri. Environ Technol. 24:1501-1508.

Chang, J.S. and J. Hong. 1994. Biosorption of mercury by the inactivated cells of Pseudomonas aeruginosa PU 21 (Rip 64). Biotechnol. Bioeng. 44:999-1006.

Chang J.S., R. Law, and C.C. Chang. 1997. Biosorption of lead, copper and cadmium by biomass of Pseudomonas aeruginosa PU21. Wat. Res. 31:1651-1658.

Chen, P. and Y.P. Ting. 1995. Effect of heavy metal uptake on the electrokinetic properties of Saccharomyces cerevisiae. Biotechnol. Lett. 17:107.

Chen, X.C., Y.P. Wang, Q. Lin, J.Y. Shi, W.X. Wu, and Y.X. Chen. 2005. Biosorption of copper(II) and zinc(II) from aqueous solution by Pseudomonas putida CZ1. Colloids Surf. B. Biointerfaces. 46:101-107.

Chergui, M., Z. Bakhti, A. Chahboub, S. Haddoum, A. Selatnia, and G.A. Junter. 2007. Simultaneous Biosorption of $\mathrm{Cu}^{2+}, \mathrm{Zn}^{2+}$ and $\mathrm{Cr}^{6+}$ from Aqueous Solution by Streptomyces rimosus Biomass. Desal. 206:179-184.

Cho, D.Y., S.T. Lee, S.W. Park, and A.S. Chung. 1994. Studies on the biosorption of heavy metals onto Chlorella vulgaris, J. Environ. Sci. Health. Part A. 29:389-409.

Choi, S.B. and Y.S. Yun. 2004. Lead biosorption by waste biomass of Corynebacterium glutamicum generated from lysine fermentation process Biotechnol. Lett. 26:331-336.

Chong, K.H. and B. Volesky. 1995. Description of 2-metal biosorption equilibria by Langmuir-type models. Biotechnol. Bioeng. 47:451-460.

Collins, Y. E. and G. Stotzky. 1992. Heavy metals alter the electrokinetic properties of bacteria, yeasts and clay minerals. Appl. Environ. Microbiol. 58:1592-1600.

Das, G., D.K. Thotala, S. Kapoor, S. Karunanithi, S.S. Thakur, N.S. Singh, and U. Varshney. 2008. Role of 16S ribosomal RNA methylations in translation initiation in Escherichia coli. EMBO J. 27:840-851. 
Delgado, A., A.M. Anselmo, and J.M. Novais. 1998. Heavy metal biosorption by dried powdered mycelium of Fusarium flocciferum. Water Environ. Res. 70:370-375.

Dilek, F.B., A. Erbay, U. Yetis. 2002. Ni(II) biosorption by polyporus versicolor. Processes Biochem. 37:723-726.

Esposito, D., A.J. Hicks, and D.B. Stern. 2001. A role for initiation codon context in chloroplast translation. Plant Cell. 13:2373-2384.

Febrianto, J., A,N. Kosasih, J. Sunarso, Y.H. Ju, N. Indraswati, and S. Ismadji. 2009. Equilibrium and kineticstudies in adsorption of heavy metals using biosorbent: a summary of recent studies. J Hazard Mater. 162:616-645.

Fourest, E. and J.C. Roux. 1992. Heavy metal biosorption by fungal mycelial by-products: mechanisms and influence of $\mathrm{pH}$. Appl. Microbiol. Biotechnol. 37:399-403.

Fourest, E., C. Canal, and J.C. Roux. 1994. Improvement of heavy metals biosorption by mycelial dead biomass (Rhizopus arrhizus, Mucor meihi and Penicillium chrysogenum): $\mathrm{pH}$ control and cationic activation. FEMS Microbiol. Rev. 14:325-332.

Friis, N. and P.M. Keith. 1998. Biosorption of uranium and lead by Streptomyces longwoodensis. Biotechnol. Bioeng. 28:21-28.

Gabr, R.M., S.H.A. Hassan, and A.A.M. Shoreit. 2008. Biosorption of lead and nickel by living and non-living cells of Pseudomonas aeruginosa ASU 6a. Int. Biodeterior. Biodegradation 62:195-203.

Gabriel, J., J. Vosahlo, and P. Baldrian. 1996. Biosorption of cadmium to mycelial pellets of wood-rotting fungi. Biotechnol. Lett. 10:345-348.

Gadd, G. 1992. Metals and microorganisms: a problem of definition. FEMS Microbiol. Lett. 100:197-204.

Gadd, G.M. 1993. Interactions of fungi with toxic metals. New Phytol. 124:25-60.

Gadd, G.M. 1987. Fungal response towards heavy metals. In: Herbert, R.A. and Codd, G.A., Editors. 1987. Microbes in Extreme Environments, Academic Press, London. 84-109.

Gadd, G.M., C. White, and L. de Rome. 1988. Heavy metal and radionuclide uptake by fungi and yeasts. In BioHydro Metallurgy: Proceedings of the International Symposium; Norris, P. R., Kelly, D. P., Eds.; Sci. Tech. Letters: Kew, Surrey, U.K. 421-436.

Galun, M., E. Galun, B.Z. Siegel, P. Keller, H. Lehr, and S.M. Siegel. 1987. Removal of metal ions from aqueous solutions by Penicillium biomass: kinetic and uptake parameters. Water, Air Soil Poll. 33:359-371.

Godlewska Zylkiewicz, B. 2006. Microorganisms in inorganic chemical analysis. Anal. Bioanal. Chem. 38:114-123.

Göksungur, Y., S. Üren, and U. Güvenc. 2005. Biosorption of Cadmium and Lead Ions by Ethanol Treated Waste Baker's Yeast Biomass.” Bioresourc Technol. 96:103-109.

Gonen, T.F., M. Yamac, A. Cabuk, and Z. Yildiz. 2008. Selection of newly isolated mushroom strains for tolerance and biosorption of zinc in vitro. J. Microbiol. Biotechnol. 18:483-489.

Goyal, N., S.C. Jain, and U.C. Banerjee. 2003. Comparative studies on the microbial adsorption of heavy metals. Adv. Environ. Res. 7:311-319.

Hassan, S.H.A., S.J. Kim, A.Y. Jung, J.H. Joo, S.E. Oh, and J.E. Yang. 2009. Biosorptive capacity of $\mathrm{Cd}$ (II) and $\mathrm{Cu}$ (II) by lyophilized cells of Pseudomonas stutzeri. J. Gen. Appl. Microbiol. 55:27-34.
Ho, Y.S. and G. McKay. 1999. The sorption of lead(II) ions on peat. Water Res. 33:578-584.

Ho, Y.S. and G. McKay. 1998. The kinetics of sorption of basic dyes from aqueous solution by Sphagnum moss peat, Can. J. Chem. Eng. 76:822-827.

Holan, Z.R. and B. Volesky. 1995. Accumulation of cadmium, lead and nickel by fungal and wood biosorbents. Appl. Biochem. Biotechnol. 53:133-146.

Huang, and C.P. Huang. 1996. Application of Aspergillus oryzae and Rhizopus oryzae for Cu(II) removal, Water Res. 30:1985-1990.

Ivanov, K., E. Gruber, W. Schempp, and D. Kirov. 1996. "Possibilities of using zeolite as filler and carrier for dyestuffs in paper". Das Papier, 50:456460.

Jarosz-Wilkolazka A., Kochmanska-Rdest J., Malarczyk E., Wardas W., and Leonowicz, A. 2002. Fungi and their ability to decolourize azo and anthraquinonic dyes. Enzyme Microb. Technol. 30:566-572.

Jarosz-Wilkolazka, A., M. Graz, B. Braha, S. Menge, and G.J. Krauss. 2006. Species-specific Cd-stress response in the white rot basidiomycetes Abortiporus biennis and Cerrena unicolor. Biometals. 19:39-49.

Javaid, A. and R. Bajwa. 2008. Biosorption of electroplating heavy metals by some basidiomycetes. Mycopath. 6:1-6.

Javaid, A. and S. Shafique. 2010. Herbicidal effects of extracts and residue incorporation of Datura metel against parthenium weed. Nat. Prod. Res. 24:1426-1437.

Jonglertjunya, W. 2008. Biosorption of lead(II) and copper(II) from aqueous solution. Chiang Mai Journal of Science. 35:69-81.

Joo, J.H. S.H.A. Hassan, and S.E. Oh. 2010. Comparative study of biosorption of $\mathrm{Zn}^{2+}$ by Pseudomonas aeruginosa and Bacillus cereus. Int. Biodet. Biodegrad. 64:734-741.

Kadukova, J. and E. Vircikova. 2005. Comparison of differences between copper bioaccumulation and biosorption. Environ. Int. 31:227-232.

Kaewsarn, P. 2002. Biosorption of copper(II) from aqueous solutions by pre-treated biomass of marine algae Padina sp. Chemosphere. 47:1081-1085.

Kao, W.C., C.C. Huang, and J.S. Chang. 2008. Biosorption of nickel, chromium and zinc by MerP-expressing recombinant Escherichia coli. J. Hazard. Mater. 158:100-106.

Kapoor, A. and T. Viraraghavan. 1997. Heavy metal biosorption sites in Aspergillus niger. Biores. Technol. 61:221-227.

Kapoor, A. and T. Viraraghavan. 1995. Fungi biosorption -an alternative treatment option for heavy metal bearing wastewaters: a review. Bioresour. Technol. 53:195-206.

Kapoor, A. and T. Viraraghavan. 1998. Biosorption of Heavy Metals on Aspergillus niger: Effect of Pretreatment. Bioresour. Technol. 63:109-113.

Karna, R.R., L. Uma, G. Subramanian, and P.M. Mohan. 1999. Biosorption of toxic metal ions by alkali-extracted biomass of a marine cyanobacterium, Phormidium valderianum BDU 30501. World J. Microbiol. Biotechnol. 15:729-732.

Kiff, R.J. and D.R. Little. 1986. Biosorption of Heavy Metals by Immobilized Fungal Biomass. In Immobilization of Ions by Biosorption, H. H. Eccles and S. Hunt, eds., Ellis Horwood, Chichester, West Sussex. 71. 
Khambhaty, Y., K. Mody, S. Basha, and B. Jha. 2009. Biosorption of $\mathrm{Cr}(\mathrm{VI})$ onto marine Aspergillus niger: experimental studies and pseudo-second order kinetic. World J Microbiol. Biotechnol. 25:1413:1421

Klimmek, S., H.J. Stan, A. Wilke, G. Bunke, and R. Buchholz. 2001. Comparative analysis of the biosorption of cadmium, lead, nickel, and zinc by algae. Environ. Sci. Technol. 35:4283-4288.

Kratochvil, D. and B. Volesky. 1998. Advances in the biosorption of heavy metals. Trends Biotechnol. 16:291-300.

Kumar, R., N.R. Garima, and K. Bishnoi. 2008. Biosorption of chromium(VI) from aqueous solution and electroplating wastewater using fungal biomass. Chem. Eng. J. 135:202-208.

Kumar V, L. Wati, P. Nigam, B.S. Yadav, D. Singh, and R. Marchant. 1998. Decolorization and biodegradation of anaerobically digested surgarcane molasses spent wash effluent from biomethanation plants by white-rot fungi. Process Biochem. 33:83-88.

Kuyucak, N. and B. Volesky. 1988. Biosorbents for recovery of metals from industrial solutions. Biotechnol. Lett. 10:137-142.

Leung W.C., H. Chua, and W.H. Lo. 2001. Biosorption of heavymetals by bacteria isolated from activated sludge. Appl. Biochem. Biotechnol. 91:171-84.

Li, Q, S. Wu, G. Liu, X. Liao, and X. Deng. 2004. Daohua Sun, Yuelin Hu, Yili Huang. Simultaneous biosorption of cadmium(II) and lead(II) ions by pretreated biomass of Phanerochaete chrysosporium. Sep. Purif. Technol. 34:135-142.

Lin, C.C. and Y.T. Lai. 2006. Adsorption and recovery of lead(II) from aqueous solutions by immobilized Pseudomonas aeruginosa PU21 beads. J. Hazard. Mater. 137:99-105.

Loukidou, M.X., A.I. Zouboulis, T.D. Karapantsios, and K.A. Matis. 2004. Equilibrium and kinetic modeling of chromium (VI) biosorption by Aeromonas caviae. Colloids and Surfaces A: Physicochem. Eng. Aspects. 242:93-104.

Lu, W.B., J.J. Shi, C.H. Wang, and J.S. Chang. 2006. Biosorption of lead, copper and cadmium by an indigenous isolate Enterobacter sp. J1 possessing high heavy-metal resistance. J. Hazard. Mater. 134:80-86.

Malik, A. 2004. Metal bioremediation through growing cells. Environ. Int. 30:261-278

Mameri, N., N. Boudries, L. Addour, D. Belhocine, H. Lounici, H. Grib, and A. Pauss. 1999. Batch zinc biosorption by a bacterial nonliving Streptomyces rimosus biomass. Wat. Res. 33:1347-1354.

Mapoleto, M. and N. Torto. 2004. Trace enrichment of metal ions in aquatic environments by Saccharomyces cerevisiae. Talanta. 64:39-47.

Mapoleto, M., N. Torto, and B. Prior. 2005. Evaluation of yeast strains as possible agents for trace enrichment of metal ions in aquatic environments. Talanta. 65:930-937.

Massaccesi, G., M.C. Romero, M.C. Cazau, and A.M. Bucsinszky. 2002. Cadmium removal capacities of filamentous soil fungi isolated from industrially polluted sediments, in La Plata (Argentina). W. J. Microbiol. Biotechnol. 18:817-820.

Mattuschka, B. and G. Strauble. 1993. Biosorption of metals by a waste biomass. J. Chem. Tech. Biotechnol. 58:57-63.

Mattuschka, B., K. Junghaus, and G. Straube. 1993. Biosorption of metals by waste biomass, in Biohydrometallurgical Technologies. Proceedings of the international biohydrometallurgical symposium,
Torma, A.E., Apel, M.L. and Brierley, C.L., (eds), The Minerals, Metals and Materials Society, Warrendale, PA.

Mongollon, L., R. Rodriquez, W. Larrota, N. Ramirez, and R. Torres. 1998. Biosorption of nickel using filamentos fungi. Appl. Biochem. Biotehnol. 70:593-601.

Morillo J.A., R. García-Ribera, T. Quesada, M. Aguilera, A. Ramos-Cormenzana, and Monteoliva-Sánchez M. 2008. Biosorption of heavy metals by the EPS produced by Paenibacillus jamilae. World J. Microbiol. Biotechnol. 24:2699-2704.

Mukhopadhyay, M., S.B. Noronha, and G.K. Suraishkuma. 2007. Kinetic modeling for the biosorption of copper by pretreated Aspergillus niger biomass. Bioresource Technol. 98:1781-1787.

Mullen, M.D., D.C. Wolf, T.J. Beveridge, and G.W. Bailey. 1992. Sorption of heavy metals by the soil fungi Aspergillus niger and Mucor rouxii. Soil Biol. and Biochem. 24(2):129-135.

Nakajima, A., M. Yasuda, H. Yokoyama, H. Ohya-Nishiguchi, and H. Kamada. 2001. Copper biosorption by chemically treated Micrococcus luteus cells. World J Microbiol Biotechnol. 17: 343-347.

Niu, H, X.S. Xu, J.H. Wang, and B. Volesky. 1993. Removal of lead from aqueous solutions by Penicillium biomass. Biotechnol. Bioeng. 42:785-787.

Norton, L., K. Baskaran, and T. McKenzie. 2004. Biosorption of zinc from aqueous solutions using biosolids. Adv Environ Res. 8:629-35.

Ozer, A. and D. Ozer. 2003. Comparative study of the biosorption of $\mathrm{Pb}(\mathrm{II}), \mathrm{Ni}(\mathrm{II})$ and $\mathrm{Cr}(\mathrm{VI})$ ions onto $S$. cerevisiae: determination of biosorption heats. J. Hazardous Mater. 100:219-229.

Öztürk A., T. Artan, and A. Ayar. 2004. Biosorption of nickel(II) and copper(II) ions from aqueous solution by Streptomyces coelicolor A3 (2). Colloids Surf B Biointerfaces. 34:105-11.

Pagnanelli, F., M. Papini, M. Trifoni, L. Toro, and F. Veglio. 2000. Biosorption of metal ions on Arthrobacter sp.: Biomass characterization and biosorption modeling. Environ. Sci. Technol. 34:2773-2778.

Pardo R., M. Herguedas, E. Barrado, and M. Vega. 2003. Biosorption of cadmium, copper, lead and zinc by inactive biomass of Pseudomonas putida. Anal. Bioanal. Chem. 376:26-32.

Park, D., Y.S. Yun, and J.M., Park. 2005. Studies on hexavalent chromium biosorption by chemically-treated biomass of Ecklonia sp. Chemosphere. 60(10):1356-1364.

Parvathi, K. 2007. Lead biosorption onto waste beer yeast by-product, a means to decontaminate effluent generated from battery manufacturing industry. Electronic J. Biotechnol. 10:92-105.

Pérez, S., R.M, A.A. Rodriguez, M. Gomez, De.Oca. J.M. Cantero, and D. Moreno. 2009. Biosorption of chromium, copper, manganese and zinc by Pseudomonas aeruginosa AT18 isolated from a site contaminated with petroleum. Bioresour. Technol. 100:1533-1538.

Puranik, P.R. and K.M. Paknikar. 1997. Biosorption of lead and zinc from solutions using Streptoverticillium cinnamoneum waste biomass, J. Biotechnol. 55:113-124.

Puranik, P.R., N.S. Chabukswar, and K.M. Paknikar. 1995. Cadmium biosorption by Streptomyces pimprina waste biomass. Appl Microbiol Biotechnol. 43:1118-1121. 
Puranik, P.R. and K.M. Paknikar. 1999. Biosorption of lead, cadmium and zinc by Citrobacter strain MCM B-181: characterization studies. Biotechnol. Progress. 15:228-237.

Purvis, O.W. and C. Halls. 1996. A review of lichens in metalenriched environments. Lichenologist 28:571-601.

Rao, C.R.N., L. Iyengar, and C. Venkobachar. 1993. Sorption of copper(II) from aqueous phase by waste biomass. J. Environ. Eng. Division, Proceed. ASCE. 119:369-377.

Rashmi, K., S.T. Naga, P.V. MaruthiMohan, and G.V enkateswaran. 2004. Bioremediation of $60 \mathrm{Co}$ from simulated spent decontamination solutions. Sci. Total. Environ. 328:1-14.

Razmovski, R. and Šćiban. M. (2008): Iron(III) biosorption by Polyporus squamosus. Afri. J. Biotechnol. 7:1693-1699.

Ruiz, M.A., P.I. Magana, V. López, and R. Guzmán. 1997. Biosorption of $\mathrm{Cu}$ by Thiobacillus ferrooxidans. Bioprocess. Eng. 18:113-118.

Sag, Y., A. Kaya, and T. Kustal. 2000. Lead copper and zinc biosorption from biocomponet systems modelled by empirical Freundlich isotherm. Appl. Microbiol. Biotechnol., 53:338-341.

Sag, Y. and T. Kutsal. 2000. Determination of the biosorption heats of heavy metal ions on Zoogloea ramigera and Rhizopus arrhizus. Biochem. Eng. J. 6:145-151.

Saiano, F., M. Cacciola, O. Santa, and S. Ramirez. 2005. Metal ion adsorption by Phomopsis sp. biomaterial in laboratory experiments and real wastewater treatments. Wat. Res. 39:2273-2280.

Sakaguchi, T. and A. Nakajima. 1991. Accumulation of Heavy Metals such as Uranium and Thoruim by Microorganisms. In Mineral Bioprocessing," R. W. Smith and M. Misra, eds., The Minerals, Metals and Materials Society. Pennsylvania. p.85.

Savvaidis, I., M.N. Hughes, and R.K. Poole. 2003. Copper biosorption by Pseudomonas cepacia and other strains. World J Microbiol Biotechnol. 19:117-121.

Say, R., A. Denizli, and A.M. Yakup. 2001. Biosorption of cadmium(II), lead(II) and copper(II) with the filamentous fungus Phanerochaete chrysosporium. Bioresour. Technol. 76:67-70.

Selatnia, A., A. Boukazoula, N. Kechid, M.Z. Bakhti, A. Chergui, and Y. Kerchich. 2004. Biosorption of lead(II) from aqueous solution by a bacterial dead Streptomyces rimosus biomass. Biochem. Eng. J. 19:127-135.

Sing, C. and J. Yu. 1998. Copper adsorption and removal from water by living mycelium of white-rot fungus Phanerochaete chrysosporium. Water Res. 32:2746-2752.

Singh, H. 2006. Mycoremediation: Fungal Bioremediation. John Wiley and Sons Publication, USA. 19-25.

Tewari, N., P. Vasudevan, and B.K. Guha. 2005. Study on biosorption of $\mathrm{Cr}(\mathrm{VI})$ by Mucor hiemalis. Biochem. Eng. J. 23:185-192.

Tobin, J.M., D.G. Cooper, and R.J. Neufeld. 1984. Uptake of metal ions by Rhizopus arrhizus biomass, Appl. Environ. Microbiol. 47:821-824.

Tobin, J.M. and J.C. Roux. 1998. Mucor biosorbent for chromium removal from tanning effluent. Water Res. 32:1407-1416.

Tomko, J., M. Backor, and M. Stofko. 2006. Biosorption of heavy metals by dry fungi biomass. Acta Metallurgica Slovaca. 12:447-451.

Tsezos, M. and B. Volesky. 1981, Biosorption of uranium and thorium, Biotechnol. Bioeng. 23:583-604.

Tsezos, M., E. Remoudaki, and V. Angelatou. 1995. Systematic study on equilibrium and kinetics of biosorptive accumulation. The case of Ag and Ni. Int. Biodet. Biodeg. 35:331-332.

Tunali, S., T. Akar, A. Safazcan, I. Kiran, and A. Ozcan. 2006. Equilibrium and kinetics of biosorption of lead(II) from aqueous solutions by Cephalosporium aphidicola. Sep. Purif. Technol. 47:105-112.

Tuzen, M., K.O. Saygi, C. Usta, and M. Soylak. 2008. Pseudomonas aeruginosa immobilized multiwalled carbon nanotubes as biosorbent for heavy metal ions. Bioresour. Technol. 99:1563-1570.

Uslu, G. and M. Tanyol. 2006. Equilibrium and thermodynamic parameters of single and binary mixture biosorption of lead (II) and copper(II) ions onto Pseudomonas putida: Effect of temperature J. Hazard Mater. 135:3187-3193.

Veglió, F., F. Beolchini, and A. Gasbarro. 1997. Biosorption of toxic metals: an equilibrium study using free cells of Arthrobacter sp. Process Biochem. 2:99-105.

Veglio, F. and F. Beolchini. 1997. Removal of metals by biosorption: a review. Hydrometallurgy 44:301-16.

Veit, M.T., R.G. Tavares, S.M. Gomes-da-Costa, and T.A. Guedes. 2005. Adsorption isotherms of copper(II) for two species of dead fungi biomass. Processes. Biochem. 40:3303-3308.

Vimala, R. and N. Das. 2009. Biosorption of cadmium(II) and lead(II) from aqueous solutions using mushrooms: A comparative study. J. Hazard. Mater. 168:376-382.

Volesky, B. 1990. Biosorption by fungal biomass. In: Volesky B, Biosorption of heavy metals. Florida: CRC press. 140-171.

Volesky, B. and Z.R. Holan. 1995. Biosorption of heavy metals. Biotechnol. Prog. 11:235-250.

Volesky, B. 1994. Advances in biosorption of metals: selection of biomass types. FEMS Microbiol. Rev. 14:291-302.

Volesky, B. 1990. Biosorption and biosorbents, in Biosorption of heavy metals, edited by Volesky, B. (CRC Press, Boca Raton, Florida) 3-5.

Volesky, B. 2003. Sorption and biosorption BV Sorbex, Inc. Montreal-St. Lambert, Quebec, Canda.

Volesky, B., H. May, and Z.R. Holan. 1993. Cadmium biosorption by Saccharomyces cerevisiae. Biotechnol. Bioeng. 41:826-829.

Wang, G.X., M.C. Fuerstenau, and R.W. Smith. 1997. The mechanism of lead removal by nonliving water hyacinth roots. In: Hoberg, H., von Blottnitz, H. ŽEds.., Proceedings of the XX International Mineral Processing Congress. 5:615-628.

Wang, J. and C. Chen. 2006. Biosorption of heavy metals by Saccharomyces cerevisiae: a review, Biotechnol. Adv. 24:427-451.

Wang, J.L. and C. Chen. 2009. Biosorbents for heavy metals removal and their future a review. Biotechnol. Adv. 27:195-226.

Xia, Y. and C. Liyuan. 2002. Study of gelatinous Supports for Immobilizing Inactivated Cells of Rhizopus oligosporus to Prepare Biosorbent for Lead Ions, The Int J Environ Studies. 5:1-6.

Yakubu, N.A. and A.W.L. Dudeney. 1986. "Biosorption of uranium with Aspergillus niger. In Immobilization of Ions by Biosorption," H. H. Eccles and S. Hunt, eds., Ellis Horwood, Chichester, West Sussex. P.183.

Yan, G. and Viraraghavan. 2000. Effect of pretreatment on the bioadsorption of heavy metals on Mucor rouxii. Water SA. 
26:119-123.

Yan, G. and T. Viraraghavan. 2003. Heavy metals removal from aqueous solution by fungus mucor rouxii. Wat Rese. 37:4486-4496.

Yan, G. and T. Viraraghavan. 2008. Mechanism of Biosorption of Heavy Metals by Mucor rouxii, Eng Life Sci. 8:363-371.

Yetis, U, G. Özcengiz, F.B. Dilek, N. Ergen, A. Erbay, and A. Dölek. 1998. Heavy metal biosorption by white-rot fungi. Water Sci. Technol. 38:323-330.

Yetis, U., A. Dolek, F.B. Dilek, and G. Ozcengiz. 2000. The removal of $\mathrm{Pb}$ (II) by Phanerochaete chrysosporium. Wat. Res. 34:4090-4100.

Yilmaz, E.I. and N.Y. Ensari. 2005. Cadmium biosorption by Bacillus circulans strain EB1. World J. Microbiol. Biotechnol. 21:777-779. Yin, P., Q. Yu, B. Jin, and Z. Ling. 1999. Biosorption removal of cadmium from aqueous solution by using pretreated fungal biomass cultured from starch wastewater. Wat. Res. 33:1960-1963.

Zhou, J. L. 1999. Zinc biosorption by Rhizopus arrhizus and other fungi. Appl. Microbiol. Biotech. 51:686-693.

Ziagova, M., G. Dimitriadis, D. Aslanidou, X. Papaioannou, E.L. Tzannetaki, and M. Kyriakides. 2007. Comparative study of $\mathrm{Cd}(\mathrm{II})$ and $\mathrm{Cr}(\mathrm{VI})$ biosorption on Staphylococcus xylosus and Pseudomonas sp. in single and binary mixtures. Bioresour. Technol. 98:2859-2865. 